\title{
Palladium-Catalyzed [3+2] Cycloaddition of Carbon Dioxide and Trimethylenemethane under Mild Conditions.
}

\author{
George E. Greco*, Brittany L. Gleason, Tiffany A. Lowery, Matthew J. Kier, Lisa B. Hollander, \\ Shoshanah A. Gibbs, and Amanda D. Worthy \\ Department of Chemistry, Goucher College, 1021 Dulaney Valley Road, Baltimore MD 21204.
}

\section{Supporting Information}

\section{Synthesis of Substituted Substrates}

Substrates $\mathbf{2 b}$ and $\mathbf{2 c}$ were both originally prepared by Trost. ${ }^{1}$ We found Malacria's route to $\mathbf{2 b}$ based on a radical cyclization ${ }^{2}$ (Scheme S1) to be more appealing than Trost's original route because it does not involve working with the dianion of 3-methyl-3-buten-2-ol, ${ }^{3}$ and it provided us with $\mathbf{2 b}$ in $20 \%$ overall yield.

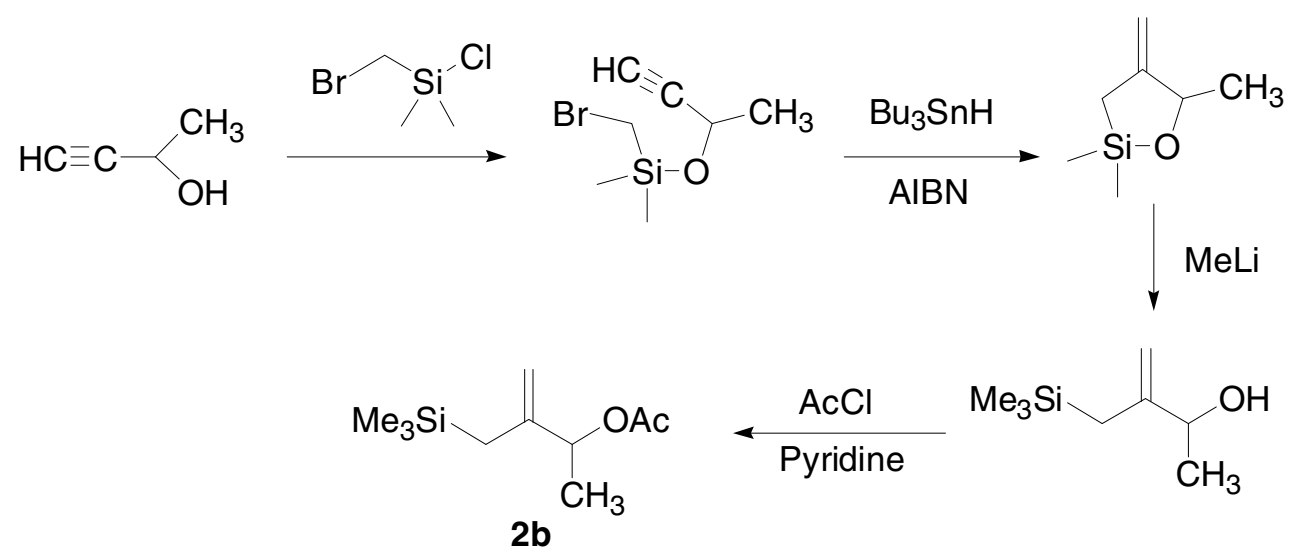

Scheme S1. Synthetic Route to substrate $2 \mathbf{b}$.

Substrate $2 \mathbf{c}$ was synthesized according to the route in Trost's original publication, ${ }^{1}$ which provides the compound in $41 \%$ overall yield. Full experimental details are provided here. Specifically, if the reaction is carried out at $0.2 \mathrm{M}$ concentration in THF as the solvent, and it is heated under reflux $\left(66^{\circ} \mathrm{C}\right)$ for 48 hours, the expected reduction product is formed.

Trost's published procedure references an earlier paper by Marshall on the $\mathrm{LiAlH}_{4}$ reduction of malonic enolates. ${ }^{4}$ If the $\mathrm{LiAlH}_{4}$ reduction is carried out under Marshall's exact 
conditions (DME (b.p. $85^{\circ} \mathrm{C}$ ) as the solvent, and $0.65 \mathrm{M}$ concentration), a stereospecific $[1,3]$ sigmatropic migration of the trimethylsilyl fragment ${ }^{5}$ takes place, providing a facile entry into previously unknown substrate $\mathbf{2 d}$. Control experiments have shown that both the increased temperature and concentration are required for the rearrangement to take place. It is also noteworthy that under these conditions, the reaction is complete in 3 hours. In a more recent paper, Trost reported the synthesis of the alcohol precursor to $\mathbf{2 d}((Z)-2$-trimethylsilylmethyl-2buten-1-ol) by a different route that was known to give the $(Z)$ stereochemistry. ${ }^{6}$ While we do not routinely purify this alcohol as a result of its thermal instability, comparison of the ${ }^{1} \mathrm{H}$ NMR spectrum of a purified sample to the data reported by Trost confirms that the alkene stereochemistry of our product is also $(Z)$.

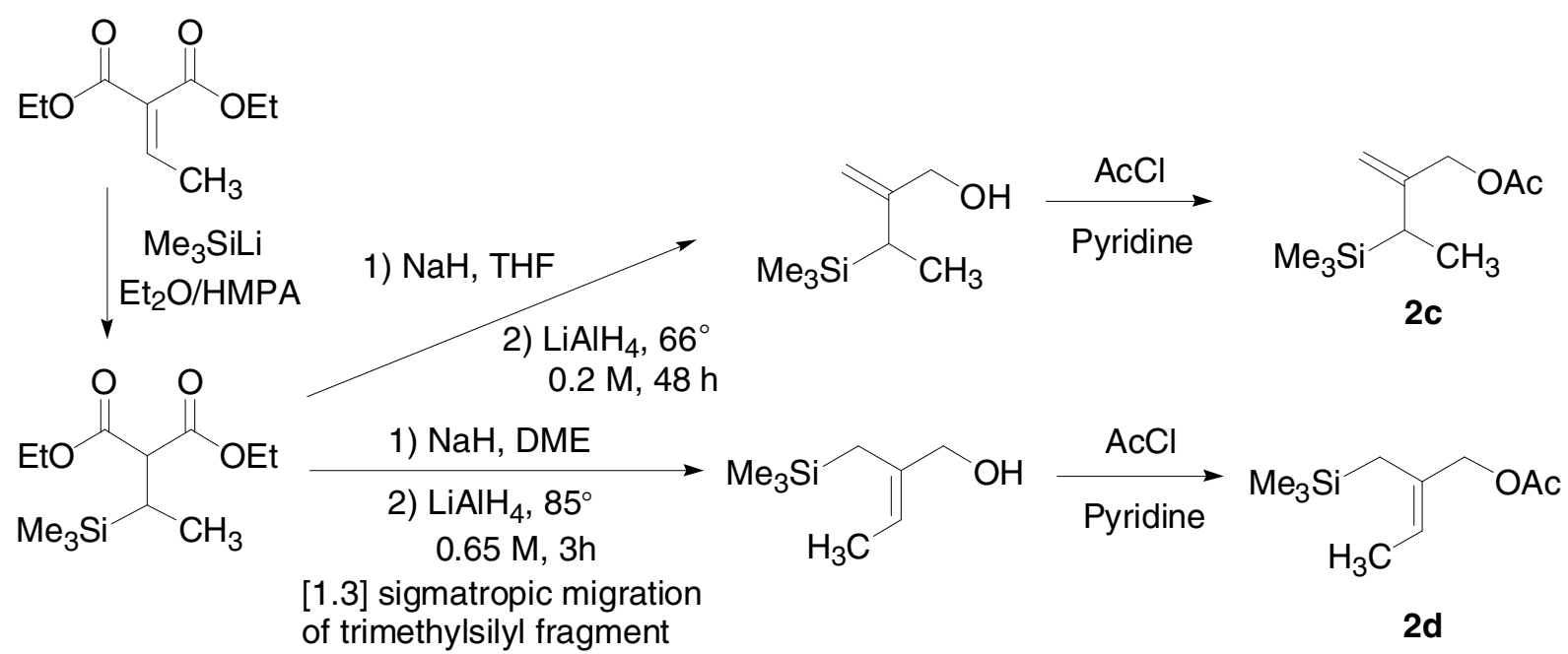

Scheme S2. Synthesis of Substrates $2 \mathbf{c}$ and $\mathbf{2 d}$.

\section{Experimental Details}

General Procedures. All anhydrous reactions were performed in oven- or flame-dried glassware. All reactions were magnetically stirred. THF, diethyl ether and toluene were distilled from sodium benzophenone ketyl. Anhydrous DME was purchased from Aldrich and stored in a 
glove box. Diphenylmethylenecyclopropane was prepared in 3 steps following literature procedures. $^{7,8}$ All other chemicals were purchased from commercial suppliers and used as received. All solutions were concentrated down using a rotary evaporator. Plastic-support precoated silica gel Whatman TLC plates were used. The best stain used for visualization was potassium permanganate. All GC/MS spectra were obtained on a Shimadzu QP-5000 spectrometer $(\mathrm{EI}, 70 \mathrm{eV})$ with default oven temperature program: $80^{\circ} \mathrm{C}-280^{\circ} \mathrm{C}\left(20^{\circ} / \mathrm{min}\right)$ and a hold time of 0 minutes. NMR spectra were determined in chloroform- $d$ using a Bruker DRX 400 MHz spectrometer. The ${ }^{1} \mathrm{H}$ NMR spectra of compounds $\mathbf{1 a},{ }^{9} \mathbf{1 b},{ }^{10} \mathbf{1 c},{ }^{11} \mathbf{2 b},{ }^{1}$ and $\mathbf{2} \mathbf{c}^{\mathbf{1}}$ were identical to those reported in the literature. IR spectra were recorded as thin films on $\mathrm{NaCl}$ plates on a Thermo Nicolet Avatar 370 FTIR spectrometer. High Resolution Mass Spectra were performed at The Johns Hopkins University Department of Chemistry Mass Spectrometry Facility on a VG Analytical VG 70S Mass Spectrometer operating in EI mode.

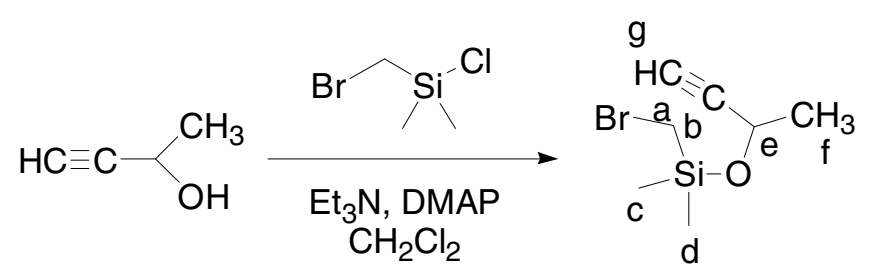

Bromomethyldimethylsilyl-3-butyn-2-yl ether. ${ }^{2}$ Triethylamine (17.5 mL, $\left.125 \mathrm{mmol}\right), 3$ butyn-2-ol (1.75 g, $25.0 \mathrm{mmol})$, and DMAP $(0.153 \mathrm{~g}, 1.25 \mathrm{mmol})$ were added to a solution of (bromoethyl)chlorodimethylsilane $(5.15 \mathrm{~g}, 27.5 \mathrm{mmol})$ in dichloromethane $(100 \mathrm{~mL})$. The reaction was stirred overnight under nitrogen at room temperature, during which time a white precipitate formed, and the solution turned orange. The solvent was removed, and the residue was partitioned between ether $(35 \mathrm{~mL})$ and $1 \mathrm{M} \mathrm{HCl}(100 \mathrm{~mL})$. The layers were separated, and the organic layer was washed with a second $50 \mathrm{~mL}$ portion of $1 \mathrm{M} \mathrm{HCl}$. The aqueous layer was 
washed with ether, then the combined organic extracts were washed twice with saturated $\mathrm{NaHCO}_{3}$, dried over $\mathrm{MgSO}_{4}$, and concentrated. The product was purified by column chromatography on silica gel, eluting with 5\% ether in pentane to yield a colorless liquid (2.976 g, $13.5 \mathrm{mmol}, 54 \%) .{ }^{1} \mathrm{H} \mathrm{NMR}\left(\mathrm{CDCl}_{3}, 400 \mathrm{MHz}\right) \delta 4.60\left(\mathrm{qd}, \mathrm{J}=6.6,2.2 \mathrm{~Hz}, 1 \mathrm{H}, \mathrm{H}_{\mathrm{e}}\right), 2.58(\mathrm{~d}, \mathrm{~J}$ $\left.=13 \mathrm{~Hz}, 1 \mathrm{H}, \mathrm{H}_{\mathrm{a}}\right), 2.53\left(\mathrm{~d}, \mathrm{~J}=13 \mathrm{~Hz}, 1 \mathrm{H}, \mathrm{H}_{\mathrm{b}}\right), 2.43\left(\mathrm{~d}, \mathrm{~J}=2.2,1 \mathrm{H}, \mathrm{H}_{\mathrm{g}}\right), 1.45(\mathrm{~d}, \mathrm{~J}=6.6 \mathrm{~Hz}, 3 \mathrm{H}$, $\left.\mathrm{H}_{\mathrm{f}}\right), 0.34\left(\mathrm{~s}, 3 \mathrm{H}, \mathrm{H}_{\mathrm{c}}\right), 0.33\left(\mathrm{~s}, 3 \mathrm{H}, \mathrm{H}_{\mathrm{d}}\right) .{ }^{13} \mathrm{C} \mathrm{NMR}\left(\mathrm{CDCl}_{3}, 100 \mathrm{MHz}\right) \delta 85.6,72.2,59.0,25.1$, 16.1, -2.6, -2.7. MS: $m / z=127(100 \%), 219\left(\mathrm{M}-1^{+}, 0.3 \%\right), 221\left(\mathrm{M}-1^{+}, 0.3 \%\right)$.

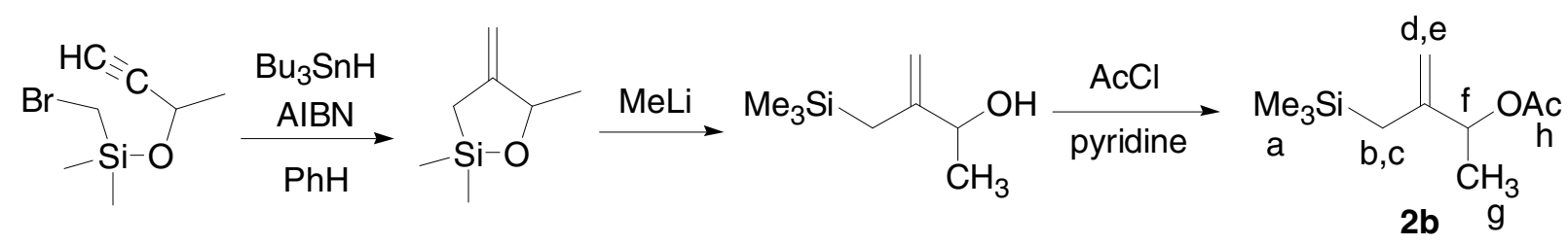

(2-(1'-acetoxyethyl)-2-propenyl)trimethylsilane (2b). ${ }^{2}$ A solution of $n-\mathrm{Bu}_{3} \mathrm{SnH}(2.77$

g, $9.54 \mathrm{mmol})$ and AIBN $(2.52 \mathrm{~mL}, 0.867 \mathrm{mmol})$ in benzene (total solution volume $=29 \mathrm{~mL}$ ) was added by syringe pump at a rate of $2 \mathrm{~mL} / \mathrm{h}$ to a refluxing solution of bromomethyldimethylsilyl-3-butyn-2-yl ether (1.92 g, $8.67 \mathrm{mmol})$ in benzene $(120 \mathrm{~mL})$ under nitrogen. The cyclized product was identified by GC/MS (2.3 $\mathrm{min} \mathrm{rt} ; \mathrm{m} / z=127(100 \%), 144$ $(1.14 \%))$, then the reaction was cooled to $0{ }^{\circ} \mathrm{C}$, and methyllithium $(15.9 \mathrm{~mL}$ of a $1.6 \mathrm{M}$ solution in ether, $26.01 \mathrm{mmol}$ ) was added over the course of $20 \mathrm{~min}$. The reaction was quenched with water, and the layers were separated (addition of saturated $\mathrm{NaCl}$ was required to break up emulsions). The aqueous layer was extracted with ether, and the combined organic extracts were dried over $\mathrm{MgSO}_{4}$, filtered and concentrated to yield 3-trimethylsilylmethyl-3-buten-2-ol as a yellow oil MS: $\left.m / z=73(100 \%), 143\left(\mathrm{M}-15^{+}, 2.48 \%\right)\right)$. Without purification, this residue was immediately dissolved in dichloromethane $(50 \mathrm{~mL})$ and cooled to $0^{\circ} \mathrm{C}$. Pyridine $(2.15 \mathrm{~mL}, 26.6$ mmol) was added followed by a dropwise addition of acetyl chloride ( $2.09 \mathrm{~g}, 26.6 \mathrm{mmol})$. After 
stirring for 10 minutes, the reaction was quenched with water followed by $20 \mathrm{~mL}$ of $1 \mathrm{M} \mathrm{HCl}$. The layers were separated, the organic layer was extracted twice with saturated $\mathrm{NaHCO}_{3}$, dried with $\mathrm{MgSO}_{4}$, and concentrated. The product was purified by column chromatography on silica gel, eluting with $5 \%$ ether in pentane to yield a colorless oil $(0.650 \mathrm{~g}, 3.25 \mathrm{mmol}, 37 \%) .{ }^{1} \mathrm{H}$ NMR $\left(\mathrm{CDCl}_{3}, 400 \mathrm{MHz}\right) \delta 5.19\left(\mathrm{q}, 1 \mathrm{H}, \mathrm{H}_{\mathrm{f}}\right), 4.89\left(\mathrm{t}, J=1.1 \mathrm{~Hz}, 1 \mathrm{H}, \mathrm{H}_{\mathrm{d} \text { or e }}\right), 4.67$ (br. s, $1 \mathrm{H}, \mathrm{H}_{\mathrm{d} \text { or }}$ e), $2.06\left(\mathrm{~s}, 3 \mathrm{H}, \mathrm{H}_{\mathrm{h}}\right), 1.59\left(\mathrm{dd}, J=14.1,1.1 \mathrm{~Hz}, 1 \mathrm{H}, \mathrm{H}_{\mathrm{b}}\right), 1.46\left(\mathrm{~d}, J=14.1,1.1 \mathrm{~Hz}, 1 \mathrm{H}, \mathrm{H}_{\mathrm{c}}\right), 1.31$ $\left(\mathrm{d}, 3 \mathrm{H}, \mathrm{H}_{\mathrm{g}}\right), 0.04\left(\mathrm{~s}, 9 \mathrm{H}, \mathrm{H}_{\mathrm{a}}\right)$. MS: $m / z=73(100 \%), 200\left(\mathrm{M}^{+}, 0.1 \%\right)$.

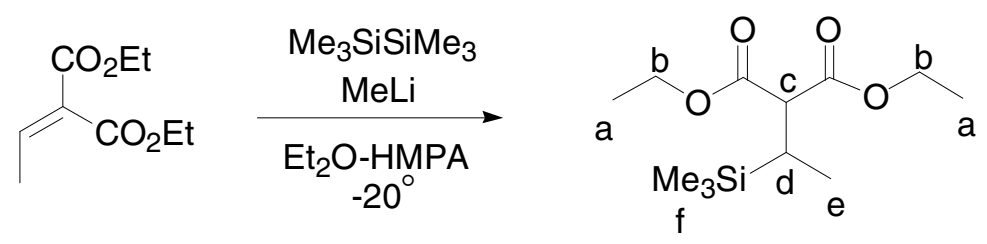

Diethyl 2-(1-trimethylsilyl)ethylmalonate. ${ }^{\mathbf{1 2}}$ A solution of hexamethyldisilane $2.342 \mathrm{~g}$ (16.00 mmol) in 5:1 ether : HMPA $(78 \mathrm{~mL})$ was cooled to $-20^{\circ} \mathrm{C}$. Methyllithium $(1.5 \mathrm{M}$ in ether) was added until a pale orange color persisted, then an additional $10 \mathrm{~mL}(15 \mathrm{mmol})$ were added dropwise via syringe and the reaction mixture was stirred for $10 \mathrm{~min}$ at $-20{ }^{\circ} \mathrm{C}$. A solution of diethyl ethylidenemalonate $(1.862 \mathrm{~g}, 10 \mathrm{mmol})$ in ether $(6.6 \mathrm{~mL})$ was added dropwise via syringe and stirred for $5 \mathrm{~min}$. The reaction solution was quenched with methanol until the deep red color became pale yellow, followed by saturated aqueous $\mathrm{NH}_{4} \mathrm{Cl}$. Water was added to dissolve any $\mathrm{NH}_{4} \mathrm{Cl}$ that precipitated out. The layers were separated; the aqueous layer was washed with pentane, and the combined organic layers were washed twice with water, dried over $\mathrm{MgSO}_{4}$, filtered, and concentrated. The product was purified by vacuum distillation (b.p. $78^{\circ} \mathrm{C}$ at 0.3 torr) to yield a colorless oil $(2.186 \mathrm{~g}, 8.39 \mathrm{mmol}, 84 \%) .{ }^{1} \mathrm{H} \mathrm{NMR}\left(400 \mathrm{MHz}, \mathrm{CDCl}_{3}\right) \delta 4.17(\mathrm{~m}$, 4H, $\left.\mathrm{H}_{\mathrm{b}}\right), 3.35\left(\mathrm{~d}, 1 \mathrm{H}, \mathrm{H}_{\mathrm{c}}\right), 1.54$ (quint., $\left.1 \mathrm{H}, \mathrm{H}_{\mathrm{d}}\right), 1.26\left(\mathrm{dt}, 6 \mathrm{H}, \mathrm{H}_{\mathrm{a}}\right), 1.01\left(\mathrm{~d}, 3 \mathrm{H}, \mathrm{H}_{\mathrm{e}}\right), 0.00(\mathrm{~s}, 9 \mathrm{H}$, 
$\left.\mathrm{H}_{\mathrm{f}}\right) .{ }^{13} \mathrm{C} \mathrm{NMR}\left(\mathrm{CDCl}_{3}, 100 \mathrm{MHz}\right) \delta 169.7,169.5,61.1,60.9,54.0,20.4,14.0,13.9,12.4,-2.7$. MS: $m / z=69(100 \%), 245\left(\mathrm{M}-15^{+}, 4.7 \%\right)$.

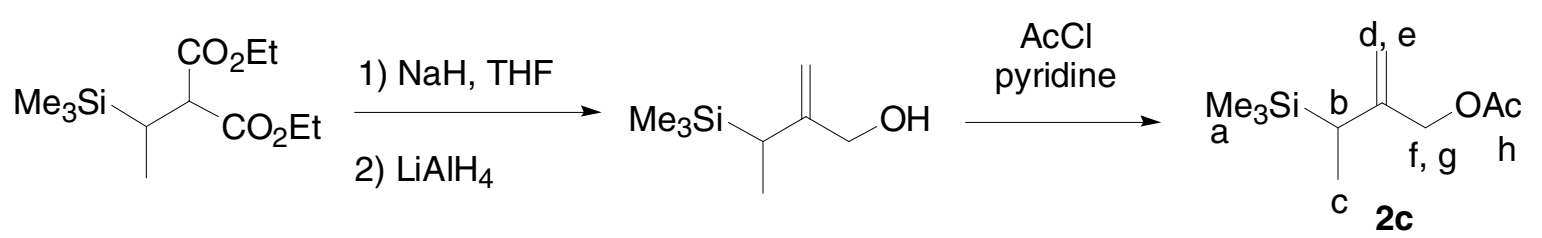

(2-(acetoxymethyl)-1-buten-3-yl)trimethylsilane (2c). ${ }^{1}$ Solid NaH (308 mg, $12.0 \mathrm{mmol}$ ) was added to a stirring solution of diethyl 2-(1-trimethylsilyl)ethylmalonate $(2.60 \mathrm{~g}, 10.0 \mathrm{mmol})$ in THF $(50 \mathrm{~mL})$. The reaction was heated under reflux for 45 minutes under nitrogen, during which time it became mostly clear and turned yellow. $\mathrm{LiAlH}_{4}(1.51 \mathrm{~g}, 40 \mathrm{mmol})$ was then added slowly as a solid. The reaction was heated under reflux for 48 hours, after which time a GC showed that the reaction was complete. After the reaction was cooled to $0{ }^{\circ} \mathrm{C}$, methyl formate (2.17 mL, $35.0 \mathrm{mmol}$ ) was added dropwise. After 5 minutes of stirring at $0{ }^{\circ} \mathrm{C}, 3 \mathrm{~mL}$ of deionized water was added dropwise followed by $3 \mathrm{~mL}$ of $2 \mathrm{M} \mathrm{NaOH}$ to render the aluminum salts granular. The salts were removed by vacuum filtration followed by washing of the filter cake with ether. The mother liquor was dried with $\mathrm{MgSO}_{4}$, filtered, and concentrated to yield 2(1- trimethylsilylethyl)-2-propen-1-ol as a yellow oil (1.234 g). Without purification, this residue was immediately dissolved in dichloromethane $(50 \mathrm{~mL})$ and cooled to $0{ }^{\circ} \mathrm{C}$. Pyridine $(1.90 \mathrm{~mL}, 23.4 \mathrm{mmol})$ was added followed by a dropwise addition of acetyl chloride (1.84 $\mathrm{g}$, $23.4 \mathrm{mmol})$. After stirring for 10 minutes, the reaction was quenched with water followed by 20 $\mathrm{mL}$ of $1 \mathrm{M} \mathrm{HCl}$. The layers were separated, the organic layer was extracted twice with saturated $\mathrm{NaHCO}_{3}$, dried with $\mathrm{MgSO}_{4}$, and concentrated. The colorless product $(978 \mathrm{mg}, 4.89 \mathrm{mmol}$, $49 \%$ ) was purified by vacuum distillation (b.p. $45-50^{\circ} \mathrm{C}$ at 0.5 torr). ${ }^{1} \mathrm{H} \mathrm{NMR}(400 \mathrm{MHz}$, $\left.\mathrm{CDCl}_{3}\right) \delta 4.97\left(\mathrm{q}, J=1.3,1 \mathrm{H}, \mathrm{H}_{\mathrm{d} \text { or e }}\right), 4.74\left(\mathrm{t}, J=1.0,1 \mathrm{H}, \mathrm{H}_{\mathrm{d} \text { or e }}\right) 4.48\left(\mathrm{dm}, J=13.6 \mathrm{~Hz}, 1 \mathrm{H}, \mathrm{H}_{\mathrm{f}}\right)$ 
$4.44\left(\mathrm{dm}, J=13.6 \mathrm{~Hz}, 1 \mathrm{H}, \mathrm{H}_{\mathrm{g}}\right), 2.10\left(\mathrm{~s}, 3 \mathrm{H}, \mathrm{H}_{\mathrm{h}}\right), 1.55\left(\mathrm{q}, 2 \mathrm{H}, \mathrm{H}_{\mathrm{b}}\right), 1.14\left(\mathrm{~d}, 3 \mathrm{H}, \mathrm{H}_{\mathrm{c}}\right), 0.01(\mathrm{~s}, 9 \mathrm{H}$, $\left.\mathrm{H}_{\mathrm{a}}\right) \cdot{ }^{13} \mathrm{C} \mathrm{NMR}\left(\mathrm{CDCl}_{3}, 100 \mathrm{MHz}\right) \delta 170.7,147.8,108.3,67.5,26.3,24.1,14.8,-3.0 . \mathrm{MS}: \mathrm{m} / \mathrm{z}=$ $67(100 \%)$, molecular ion not observed.

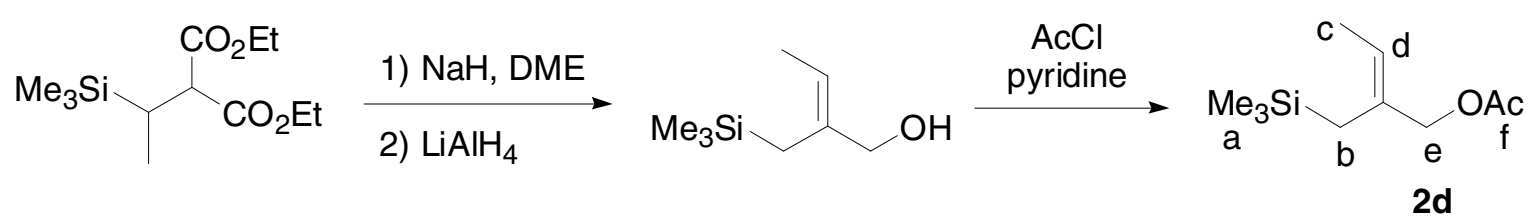

(Z)-2-acetoxymethyl-2-buten-1-yltrimethylsilane (2d). Solid NaH (233 mg, $9.22 \mathrm{mmol})$ was added to a stirring solution of diethyl 2-(1-trimethylsilyl)ethylmalonate $(2.00 \mathrm{~g}, 7.68 \mathrm{mmol})$ in DME (12 mL). The reaction was stirred at room temperature for 30 minutes under nitrogen, during which time it became mostly clear and turned yellow. $\mathrm{LiAlH}_{4}(583 \mathrm{mg}, 15.4 \mathrm{mmol})$ was then added slowly as a solid. The reaction was stirred at room temperature for 30 minutes, then heated under reflux for 3 hours, after which time a GC showed that the reaction was complete. After the reaction was cooled to $0{ }^{\circ} \mathrm{C}$ methyl formate $(0.45 \mathrm{~mL}, 7.3 \mathrm{mmol}, 0.95$ equiv) was added dropwise. After 5 minutes of stirring at $0{ }^{\circ} \mathrm{C}, 1 \mathrm{~mL}$ of deionized water was added dropwise followed by $1 \mathrm{~mL}$ of $2 \mathrm{M} \mathrm{NaOH}$ to render the aluminum salts granular. The salts were removed by vacuum filtration followed by washing of the filter cake with ether. The mother liquor was dried with $\mathrm{MgSO}_{4}$, filtered, and concentrated to yield (Z)-2-trimethylsilylmethyl-2-buten-1-ol as a yellow oil (876 mg). Without purification, this residue was immediately dissolved in dichloromethane $(25 \mathrm{~mL})$ and cooled to $0{ }^{\circ} \mathrm{C}$. Pyridine $(1.35 \mathrm{~mL}, 16.6 \mathrm{mmol})$ was added followed by a dropwise addition of acetyl chloride (1.30 g, $16.6 \mathrm{mmol})$. After stirring for 10 minutes, the reaction was quenched with water followed by $15 \mathrm{~mL}$ of $1 \mathrm{M} \mathrm{HCl}$. The layers were separated, the organic layer was extracted twice with saturated $\mathrm{NaHCO}_{3}$, dried with $\mathrm{MgSO}_{4}$, and concentrated. The colorless product (354 mg, $1.77 \mathrm{mmol}, 23 \%$ ) was purified by vacuum 
distillation (b.p. $60-65{ }^{\circ} \mathrm{C}$ at 0.3 torr). ${ }^{1} \mathrm{H}$ NMR $\left(400 \mathrm{MHz}, \mathrm{CDCl}_{3}\right) \delta 5.45\left(\mathrm{q}, 1 \mathrm{H}, \mathrm{H}_{\mathrm{d}}\right), 4.41$ (s, $\left.2 \mathrm{H}, \mathrm{H}_{\mathrm{e}}\right), 2.07\left(\mathrm{~s}, 3 \mathrm{H}, \mathrm{H}_{\mathrm{f}}\right), 1.58\left(\mathrm{~d}, 3 \mathrm{H}, \mathrm{H}_{\mathrm{c}}\right), 1.56\left(\mathrm{~s}, 2 \mathrm{H}, \mathrm{H}_{\mathrm{b}}\right), 0.04\left(\mathrm{~s}, 9 \mathrm{H}, \mathrm{H}_{\mathrm{a}}\right) .{ }^{13} \mathrm{C} \mathrm{NMR}\left(\mathrm{CDCl}_{3}\right.$, $100 \mathrm{MHz}) \delta 170.9,132.9,121.0,70.1,21.2,19.0,14.0,-0.6 . \mathrm{MS}: \mathrm{m} / z=73(100 \%), 200\left(\mathrm{M}^{+}\right.$, 0.2\%). HRMS Calcd. for $\mathrm{C}_{10} \mathrm{H}_{20} \mathrm{O}_{2} \mathrm{Si}: 200.1233$. Found (EI): 200.1226 .

Figure S1. ${ }^{1} \mathrm{H}$ NMR spectrum of purified $\mathbf{2 d}$ as evidence of sample purity.

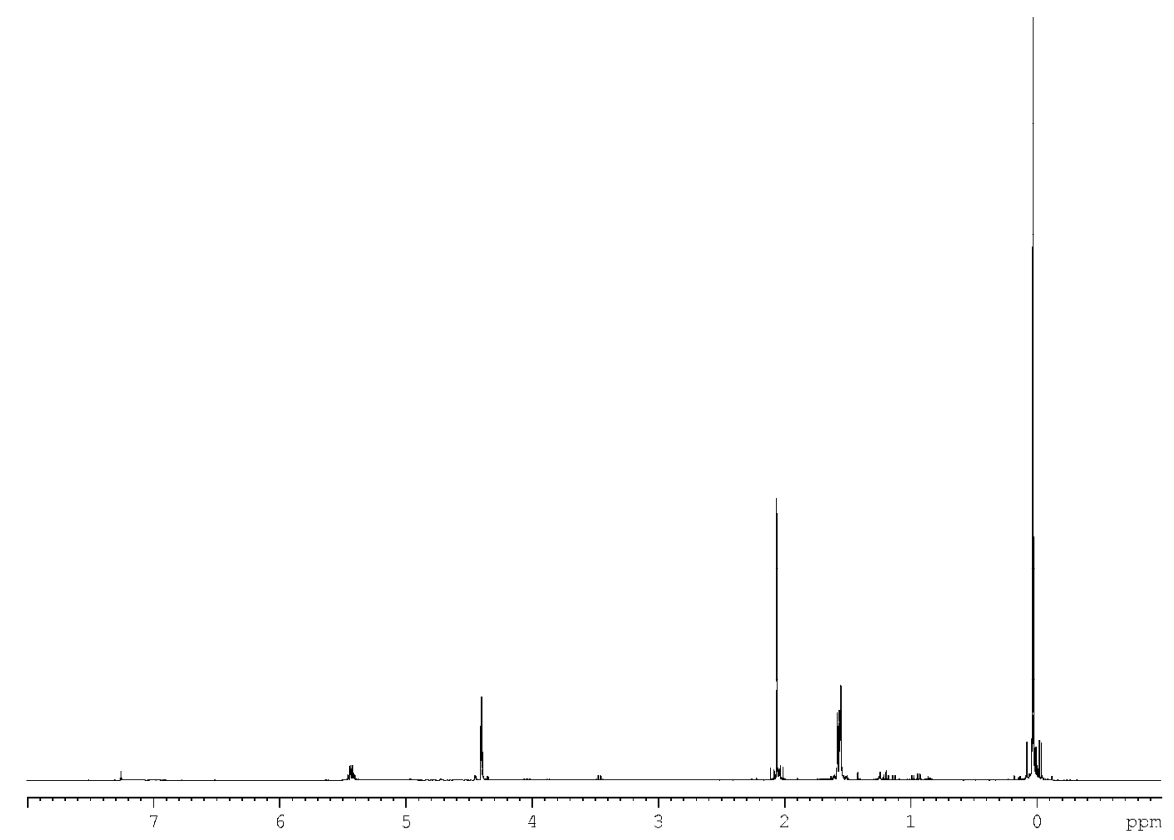

\section{Synthesis of (Z)-2-trimethylsilylmethyl-2-buten-1-ol for confirmation of}

stereochemistry. The procedure for the synthesis of $\mathbf{2 d}$ (vide supra) was followed except only $720 \mathrm{mg}$ of crude alcohol were isolated. Fractional distillation under reduced pressure (b.p. 50-60 ${ }^{\circ} \mathrm{C}$ at 0.7 torr) yielded $221 \mathrm{mg}(1.40 \mathrm{mmol}, 18 \%)$ of product as a colorless liquid. ${ }^{1} \mathrm{H}$ NMR (400 $\left.\mathrm{MHz}, \mathrm{CDCl}_{3}\right) \delta 5.38\left(\mathrm{q}, 1 \mathrm{H}, \mathrm{H}_{\mathrm{d}}\right), 3.92\left(\right.$ br. s, $\left.2 \mathrm{H}, \mathrm{H}_{\mathrm{e}}\right), 1.66\left(\mathrm{~s}, 1 \mathrm{H}, \mathrm{H}_{\mathrm{f}}\right), 1.56\left(\mathrm{~s}, 2 \mathrm{H}, \mathrm{H}_{\mathrm{b}}\right), 1.55(\mathrm{~d}$, $\left.3 \mathrm{H}, \mathrm{H}_{\mathrm{c}}\right), 0.01\left(\mathrm{~s}, 9 \mathrm{H}, \mathrm{H}_{\mathrm{a}}\right) .{ }^{13} \mathrm{C} \mathrm{NMR}\left(\mathrm{CDCl}_{3}, 100 \mathrm{MHz}\right) \delta 137.8,117.3,68.5,18.4,13.6,-0.8$. 
MS: $m / z=73(100 \%), 158\left(\mathrm{M}^{+}, 1.2 \%\right)$. The ${ }^{1} \mathrm{H}$ and ${ }^{13} \mathrm{C}$ NMR data match that reported by Trost for this compound with $(Z)$-stereochemistry. ${ }^{6}$

General Procedure for Cycloaddition Reactions. Within a nitrogen-filled glove box, a Schlenk flask was charged with substrate $2,\left(\mathrm{PPh}_{3}\right)_{4} \mathrm{Pd}$, solvent, and a stir bar. Outside the box, the solution was degassed by the freeze-pump-thaw method and refilled with $\mathrm{CO}_{2}$. The solution was stirred at full speed for five minutes to ensure $\mathrm{CO}_{2}$ saturation before heating to $55^{\circ} \mathrm{C}$ (for THF reactions) or $75^{\circ} \mathrm{C}$ (for DME reactions). After all of the starting material was consumed (by GC analysis), the reaction mixture was filtered through a plug of silica gel (rinsing with ether), then concentrated to a viscous oil. The product was purified by column chromatography on silica gel eluting with 1:1 ethyl acetate/ hexane.

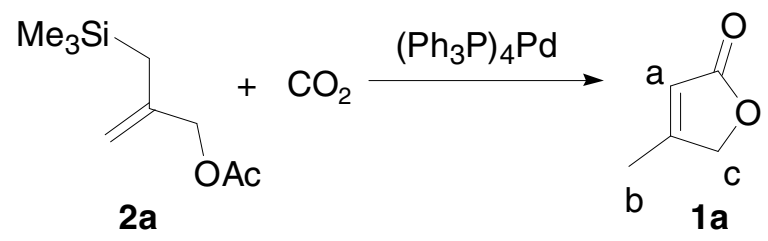

4-methyl-2-(5H)-furanone (1a). The general procedure was followed starting with $\mathbf{2 a}$ (466 mg, $2.50 \mathrm{mmol}),\left(\mathrm{PPh}_{3}\right)_{4} \mathrm{Pd}(231 \mathrm{mg}, 0.200 \mathrm{mmol})$, and $125 \mathrm{~mL} \mathrm{THF}$, yielding compound $\mathbf{1 a}$ as a pale yellow oil (152 mg, $1.55 \mathrm{mmol}, 62 \%)$ after 1.5 hours at $60{ }^{\circ} \mathrm{C} .{ }^{1} \mathrm{H} \mathrm{NMR}\left(\mathrm{CDCl}_{3}, 400 \mathrm{MHz}\right)$ $\delta 5.85\left(\mathrm{~s}, 1 \mathrm{H}, \mathrm{H}_{\mathrm{a}}\right), 4.72\left(\mathrm{~s}, 2 \mathrm{H}, \mathrm{H}_{\mathrm{c}}\right), 2.13\left(\mathrm{~s}, 3 \mathrm{H}, \mathrm{H}_{\mathrm{b}}\right) . \mathrm{MS}: \mathrm{m} / z=69(100 \%), 98\left(\mathrm{M}^{+}, 32 \%\right) . \mathrm{IR}$ $\left(\mathrm{cm}^{-1}\right) 3110(\mathrm{C}=\mathrm{C}-\mathrm{H}), 1747(\mathrm{C}=\mathrm{O}), 1644(\mathrm{C}=\mathrm{C}), 1440,1312,1143,1042,990,889,844$. 
Figure S2. ${ }^{1} \mathrm{H}$ NMR spectrum of purified 1a as evidence of sample purity.
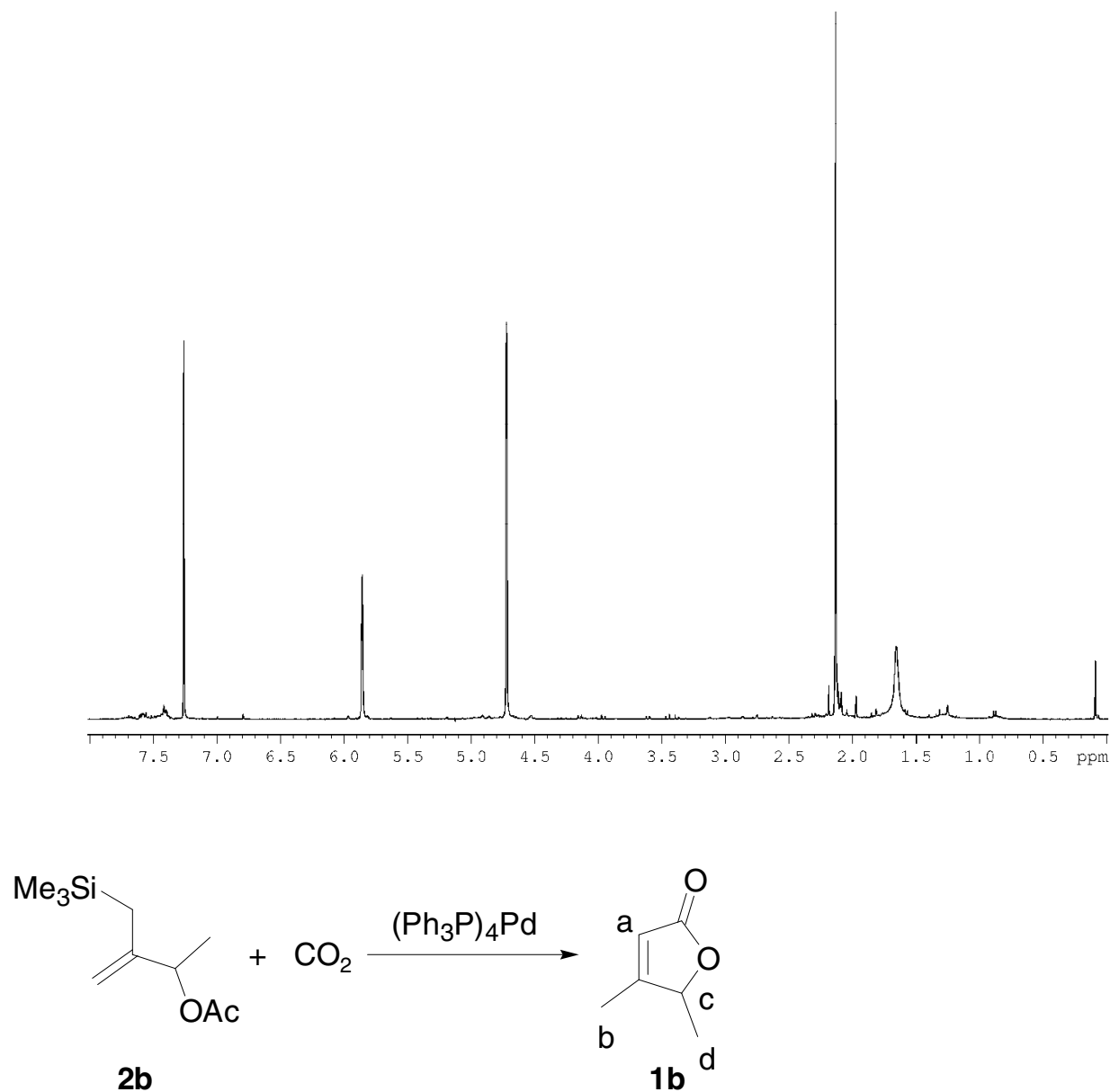

4,5-dimethyl-2-(5H)-furanone (1b). i) From 2b. The general procedure was followed starting with $2 \mathbf{b}$ (300 mg, $1.50 \mathrm{mmol}),\left(\mathrm{PPh}_{3}\right)_{4} \mathrm{Pd}(139 \mathrm{mg}, 0.120 \mathrm{mmol})$, and $75 \mathrm{~mL}$ THF, yielding compound $\mathbf{1 b}$ as a pale yellow oil $(78 \mathrm{mg}, 0.69 \mathrm{mmol}, 46 \%)$ after 18 hours at $60{ }^{\circ} \mathrm{C}$. The column was eluted with 2:1 hexane : ethyl acetate. ${ }^{1} \mathrm{H} \mathrm{NMR}\left(\mathrm{CDCl}_{3}, 400 \mathrm{MHz}\right) \delta 5.70(\mathrm{~s}, 1 \mathrm{H}$,

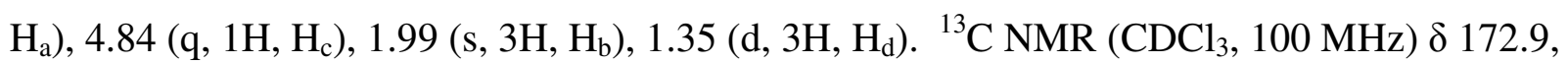
169.9, 116.0, 80.8, 17.8, 13.4. MS: $m / z=69(100 \%), 112\left(\mathrm{M}^{+}, 22 \%\right) . \quad$ IR $(\mathrm{cm}-1) 3106(\mathrm{C}=\mathrm{C}-\mathrm{H})$, $1743(\mathrm{C}=\mathrm{O}), 1645$ (C=C), 1438, 1379, 1320, 1292, 1175, 1160, 1074, 950, 890, 849, 692. 
Figure S3. ${ }^{1} \mathrm{H}$ NMR spectrum of purified $\mathbf{1 b}$ as evidence of sample purity.
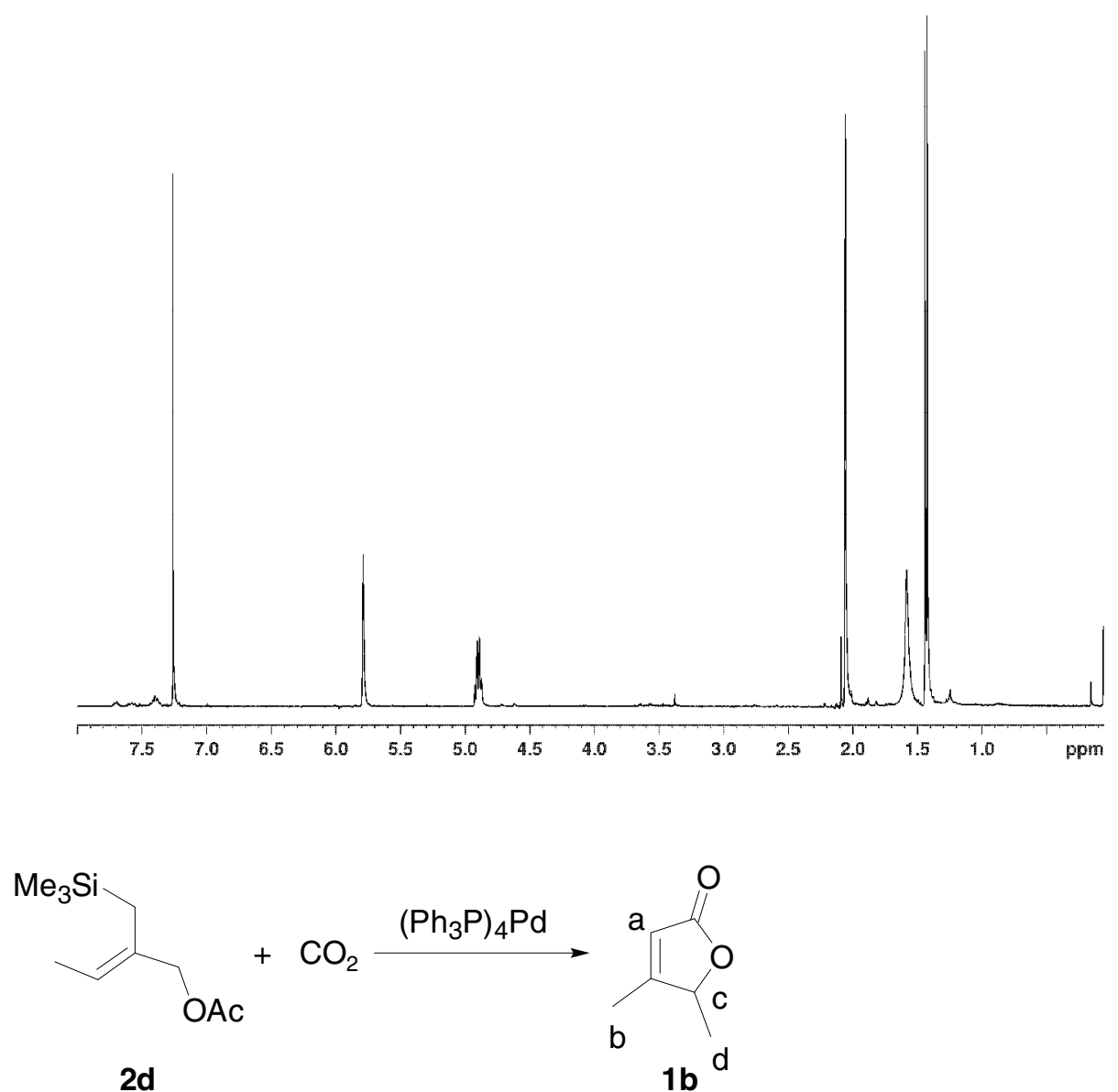

ii) From 2d. The general procedure was followed, starting with $2 d$ (200 mg, $1.00 \mathrm{mmol})$, $\left(\mathrm{PPh}_{3}\right)_{4} \mathrm{Pd}(232 \mathrm{mg}, 0.200 \mathrm{mmol})$, and DME (50 mL) yielding compound $\mathbf{1 b}$ as a pale yellow oil (30 mg, $0.27 \mathrm{mmol}, 27 \%$ yield) after 24 hours at $60^{\circ} \mathrm{C}$. The NMR yield obtained by integration of the resonance for $\mathrm{H}_{\mathrm{d}}$ against the methyl resonance in durene (vide infra) was $32 \%$. 


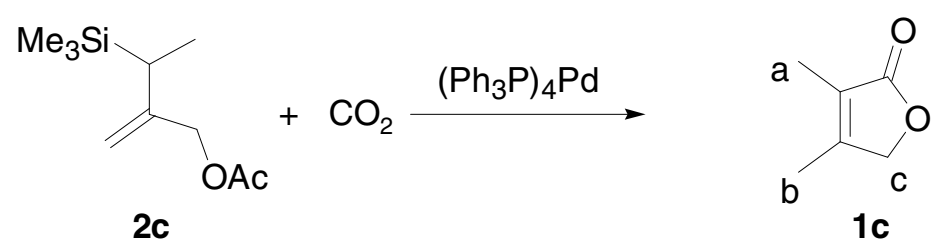

3,4-dimethyl-2(5H)-furanone (1c). The general procedure was followed starting with $2 \mathrm{c}$ (200 $\mathrm{mg}, 1.00 \mathrm{mmol}),\left(\mathrm{PPh}_{3}\right)_{4} \mathrm{Pd}(93 \mathrm{mg}, 0.080 \mathrm{mmol})$, and $50 \mathrm{~mL}$ of THF, yielding compound $1 \mathrm{c}$ as a colorless solid ( $39 \mathrm{mg}, 0.35 \mathrm{mmol}, 35 \%$ ). The NMR yield obtained by integration of the resonance for $\mathrm{H}_{\mathrm{a}}$ against the methyl resonance in durene (vide infra) was $47 \% .{ }^{1} \mathrm{H}$ NMR $\left(\mathrm{CDCl}_{3}, 400 \mathrm{MHz}\right) \delta 4.60\left(\mathrm{~m}, J=1 \mathrm{~Hz}, 2 \mathrm{H}, \mathrm{H}_{\mathrm{c}}\right), 1.99\left(\mathrm{~m}, J=1 \mathrm{~Hz}, 3 \mathrm{H}, \mathrm{H}_{\mathrm{b}}\right), 1.79(\mathrm{~m}, J=1 \mathrm{~Hz}$, $\left.3 \mathrm{H}, \mathrm{H}_{\mathrm{a}}\right) \cdot{ }^{13} \mathrm{C} \mathrm{NMR}\left(\mathrm{CDCl}_{3}, 100 \mathrm{MHz}\right) \delta 175.4,156.3,123.1,72.5,12.2,8.3 . \mathrm{MS}: \mathrm{m} / \mathrm{z}=55$ (100\%), $112\left(\mathrm{M}^{+}, 32 \%\right) . \quad \mathrm{IR}\left(\mathrm{cm}^{-1}\right) 1752(\mathrm{C}=\mathrm{O}), 1683(\mathrm{C}=\mathrm{C}), 1445,1391,1326,1081,1031$, $887,760$.

Figure S4. ${ }^{1} \mathrm{H}$ NMR spectrum of purified $1 \mathrm{c}$ as evidence of sample purity.

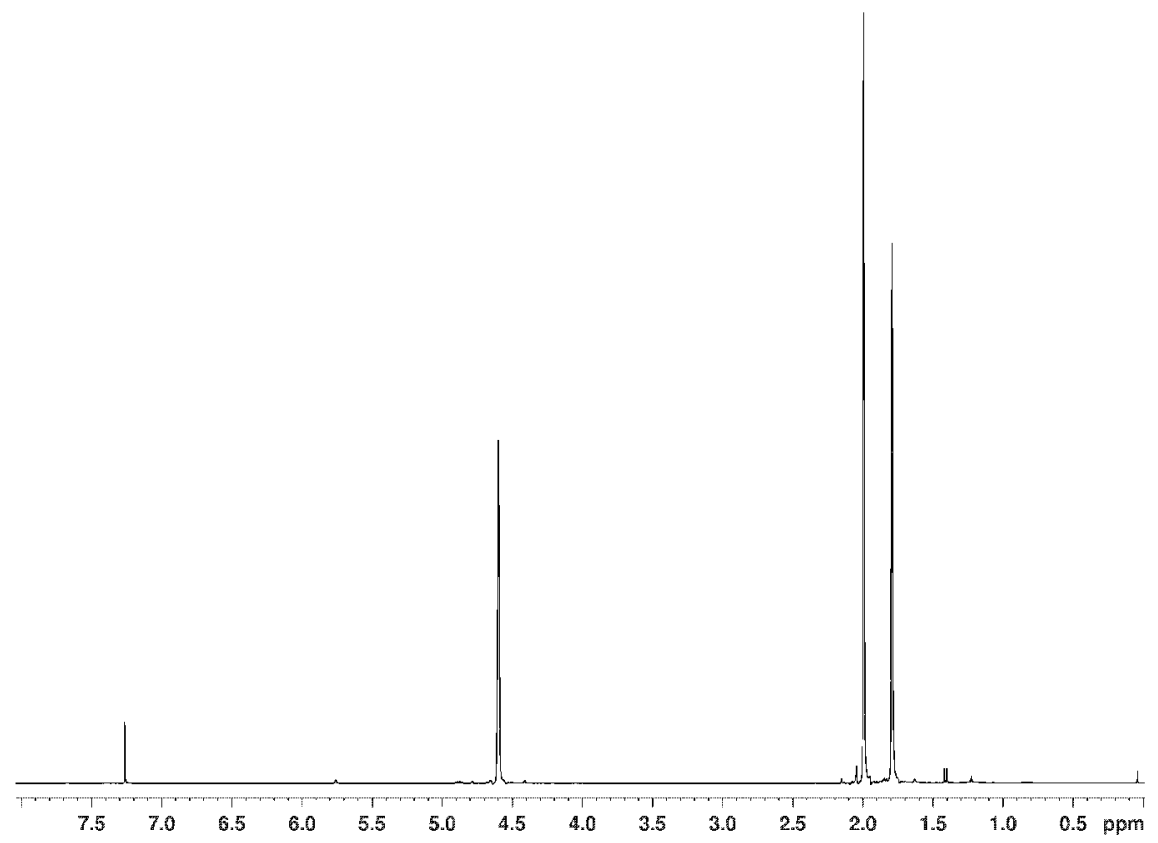


Competition Experiment between $\mathrm{CO}_{2}$ and benzylideneacetone as acceptor. The general procedure was followed, starting with $2 \mathbf{a}(93 \mathrm{mg}, 0.50 \mathrm{mmol}, 1$ equiv), benzylideneacetone (73mg, $0.50 \mathrm{mmol}, 1$ equiv), $\left(\mathrm{PPh}_{3}\right)_{4} \mathrm{Pd}(46 \mathrm{mg}, 0.040 \mathrm{mmol}, 0.08$ equiv), and $24 \mathrm{~mL}$ of THF. The reaction went overnight at $50^{\circ} \mathrm{C}$. In one experiment, the peak area ratio of $1 \mathbf{a}$ (retention time: 3.36 min (default method)) : $\mathbf{5}$ (retention time $6.90 \mathrm{~min}$ (default method)) by GC was 89:11. No attempt was made to determine a relative response factor for $\mathbf{5}$. In a second experiment, the peak for $\mathbf{5}$ was too small to be integrated. In both experiments, unreacted benzylideneacetone was the major component of the reaction mixture.

Cycloaddition with diphenyl MCP. The general procedure was followed, starting with diphenylmethylenecyclopropane (103 mg, $0.500 \mathrm{mmol})$ instead of 2a, $\left(\mathrm{PPh}_{3}\right)_{4} \mathrm{Pd}(46 \mathrm{mg}, 0.040$ mmol, 0.08 equiv), and $24 \mathrm{~mL}$ of THF. The reaction went overnight at $55^{\circ} \mathrm{C}$. GC analysis of an aliquot indicated minimal consumption of MCP (retention time: 8.07 min (default method)). A potential cycloadduct containing carbon dioxide would have a mass of 250 , and no products were present with this mass. The reaction was allowed to stir for an entire week at $55^{\circ} \mathrm{C}$, at which time GC analysis indicated little change.

Procedure for determining GC yields. A known amount of a purified sample of 1a was mixed with a known amount of mesitylene and a GC taken to determine the response factor of product 1a relative to mesitylene. The average of 4 runs gave a response factor of 0.225 (based on mass) on our instrument. A cycloaddition was carried out according to the general procedure on $93 \mathrm{mg}$ ( $0.5 \mathrm{mmol})$ of substrate $2 \mathrm{a}$. After the reaction was complete, $140 \mu \mathrm{L}$ of a $5 \%$ solution of mesitylene in toluene (containing $6.05 \mathrm{mg}$ of mesitylene) were added, and the solution was stirred vigorously to ensure complete mixing. An aliquot was taken, filtered through a plug of silica, and injected on the GC. The mass of 1a produced in the reaction was determined by 
plugging the areas of the two peaks into the equation $\mathrm{A}_{\mathbf{1 a}} / \mathrm{mass}_{\mathbf{1 a}}=\mathrm{F}\left(\mathrm{A}_{\text {mes }} / \mathrm{mass}_{\text {mes }}\right)$ and solving for $\operatorname{mass}_{1 \mathbf{a}}$, where $\mathrm{A}_{\mathbf{1 a}}=$ peak area for product $\mathbf{1 a}, \mathrm{F}=$ response factor $(0.225), \mathrm{A}_{\text {mes }}=$ area of the mesitylene peak, and mass $_{\text {mes }}=$ mass of mesitylene $(6.05 \mathrm{mg})$.

Procedure for determining NMR yields. The general procedure for a cycloaddition reaction was followed. After the reaction was complete, the reaction mixture was added to approximately $5 \mathrm{mg}$, (known to the $0.1 \mathrm{mg}$ ) of durene (1,2,4,5-tetramethyl benzene). The mixture was concentrated, a NMR was taken, and the peaks corresponding to the methyl groups on each substance were integrated. For equimolar ratios, the durene peak would be four times the product peak because its peak represents 12 hydrogens while the product peak represents 3 hydrogens. Dividing the integration of the durene peak by four gave the integration for three hydrogens. Multiplying the ratio of the integration of three hydrogens for each substance by the millimoles of durene added gave the millimoles of product in the solution. The percent yield was then determined.

Procedure for Ligand Studies. The general cycloaddition procedure was followed starting with 2a $(90 \mathrm{mg}, 0.48 \mathrm{mmol}), \mathrm{Pd}(\mathrm{OAc})_{2}(8 \mathrm{mg}, .035 \mathrm{mmol})$, and the appropriate phosphine $(0.14$ mmol; 4 equivalents relative to Pd in most cases). Reaction mixtures were analyzed by GC/MS, but product 1a was not isolated from any of these reactions.

\section{References}

(1) Trost, B. M.; Chan, D. M. T. J. Am. Chem. Soc. 1981, 103, 5972-5974.

(2) Bogen, S.; Journet, M.; Malacria, M. Synth. Commun 1994, 24, 1215-1221.

(3) Trost, B. M.; Chan, D. M. T.; Nanninga, T. N. Org. Synth. Coll. Vol., VII 1990, 266-271.

(4) Marshall, J. A.; Andersen, N. H.; Hochstetler, A. R. J. Org. Chem. 1967, 32, 113-118. 
(5) Kwart, H.; Slutsky, J. J. Am. Chem. Soc. 1972, 94, 2515-2516.

(6) Trost, B. M.; Matelich, M. C. Synthesis 1992, 151-156.

(7) Siriwardana, A. I.; Nakamura, Y.; Yamamoto, Y. Tetrahedron Lett. 2003, 44, 4547-4550.

(8) Schweizer, E. E.; Berninger, C. J.; Thompson, J. G. J. Org. Chem. 1968, 33, 336-339.

(9) Epstein, W. W.; Sonntag, A. C. J. Org. Chem. 1967, 32, 3390-3394.

(10) Gunthrum, E.; Kuhn, W.; Sponlein, W.; Jager, V. Synthesis 1986, 921-925.

(11) Woo, E. P.; Cheng, F. C. W. J. Org. Chem. 1986, 51, 3706-3707.

(12) Still, W. C. J. Org. Chem. 1976, 41, 3063-3064. 